\title{
Analysis of Financial Performance for Nagari Panampuang Saiyo Owned Enterprises
}

\author{
Erni Masdupi ${ }^{1}$, Tri Kurniawati ${ }^{2}$, Halkadri Fitra $^{3 *}$, Dini Faisal ${ }^{4}$ \\ 1,2,3,4 Universitas Negeri Padang, Padang, Indonesia, \\ *Corresponding author email: halkadri.feunp@gmail.com
}

\begin{abstract}
This study aims to see the financial performance of Nagari-Owned Enterprises (BUM-Nag) Panampuang Saiyo, Agam Regency, West Sumatra Province by using analysis of liquidity ratios, solvency, activity and profitability. The study used secondary data in the form of financial reports in 2018 and 2019. The results showed that the liquidity ratio including the current ratio, the fast ratio and the cash ratio had a large value of 1 , the solvency ratio including DAR, DER and LTDER had a small value of 1, the activity ratio included TATO and FATO have a smaller value of 1 , and the profitability ratio including ROA and ROE has a negative value. Based on these results, it is suggested that Nagari-Owned Enterprises (BUM-Nag) Panampuang Saiyo increase its business income through efforts to increase production and product marketing.
\end{abstract}

Keywords: Bumnag, performance, finance, Panampuang.

\section{INTRODUCTION}

Based on [1] Villages can establish VillageOwned Enterprises called BUMDesa (in West Sumatra Province it is called Nagari-Owned Enterprises - BumNag) which are managed with a family spirit and mutual cooperation and can run businesses in the field economy and / or public services in accordance with the provisions of laws and regulations. Data from the Ministry of Villages, Development of Disadvantaged Areas and Transmigration shows that the number of BumDesa continues to increase from 1,022 BumDes at the end of 2014 soaring to 50,199 by the end of 2019 [2]. In its establishment, BumDesa was established with initial capital from the Village Income and Expenditure Budget and subsequently it could be in the form of village capital participation and village community capital participation. The management of BumDesa consists of advisors, operational executors and supervisors. Implementers of BumDes operations have duties and obligations, have authority, and run businesses that are supervised by supervisors, reporting the implementation of BumDesa to the village head, who then the village government is responsible to the community through village deliberations [3].
The existence of BUMDesa is expected to support capacity building and participation of village communities to build villages. On the other hand, the village government is also expected to be able to have a creative and innovative pattern in dominating village economic activities through the ownership of BUMDesa so that it can build the regional economy needed to create new jobs, produce regional substitution goods and services, increase interregional government trade and provide services. optimal for consumers. Furthermore, BUMDesa was established to improve the economic life of the Village, optimize all assets owned by the village to be useful for optimizing village welfare, increase community activity efforts in managing the economic potential of the Village, expand and develop plans for business cooperation between villages and / or with third parties, creating opportunities and opportunities as well as market networks that support the need for services to the community, opening new jobs, increasing the welfare and economy of the community through improving public services, growing and equitable Village economy and increasing Village community income and Village Original Income [4].

The implementation of BumDesa's operational activities in accordance with the objectives of its establishment makes BumDesa inseparable from 
financial transactions so that BUMDesa needs financial reports that aim to present information about the financial position, profit and loss, cash flow and financial performance of a reporting entity that is useful for users in making decisions and evaluate the allocation of resources owned. One analysis that can be used in assessing and measuring the performance of a BumDesa financial report is to use financial ratio analysis. Through this financial ratio analysis, it is possible to obtain an overview of the actual financial condition of Bumdes with predetermined ratio standards.

Financial statement ratio analysis is a financial analysis tool to assess the performance of a company based on the comparison of financial data contained in the Financial Report post. In order for a BUMDesa to carry out all its activities properly, actions that need to be taken are planning, operating, controlling, and supervising. Process financial flows continuously and record them in financial reports such as balance sheets and profit and loss accounts. At first, financial statements were only a testing tool for the bookkeeping department, but subsequently financial statements were not only a testing tool but also as a basis for determining or assessing financial position or condition. Where with the results of financial analysis interested parties such as managers, creditors and investors can make decisions. Several studies that have been conducted to determine the financial performance of BumDesa include [14], [15], [16], [18], [19], and [20], show that research to see the financial performance of BumDesa is quite attractive to researchers.

Nagari-Owned Enterprise (BumNag) Panampuang Saiyo was established in 2017 initially engaged in the business of renting tents for parties then in 2018 added 1 more business sector in the field of handicrafts in the form of embroidery which was named Sulaman Pinjaik Patah and had a gallery house as a a place of business to develop embroidery and handicraft activities. In the Articles of Association, it is stated that the Panampuang Nagari Government established a Nagari-Owned Enterprise in an effort to empower, develop the community's economy, increase the income of the Nagari community and develop Nagari according to the needs and potential of the Nagari [5]. Based on the articles of association, until 2020, BumNag Panampuang Saiyo already has 2 business units, namely a tent rental business unit for wedding and meeting activities and a handicraft business unit.

BumNag Panampuang Saiyo management continues to strive to improve BumNag performance such as promoting its efforts such as promoting embroidery products by establishing the Pinjaik Patah Gallery House, online promotion, participating in exhibitions and expos at the Sail Nias Expo on Nias Island, North Sumatra [17], and Exhibition and Expo at the Malaysian State Penang Island Party. In 2019 BumNag Panampuang Saiyo received assistance in the form of Village Innovation Incubation Pilot for Local Economic Development (PIID PEL) from the Ministry of Villages for the development of the Pinjaik Patah Embroidery Craft Business [6].

As a business venture, the financial performance of Bumnag Panampuang Saiyo will be seen in the financial statements. Based on the description above, the researcher is interested in conducting research on the efforts that have been carried out by BumNag Panampuang Saiyo by looking at the financial performance of Bumnag Panampuang Saiyo by using financial ratio analysis. For this reason, the researchers formulated the problem formulation, namely: "How is the Financial Performance of Panampuang Saiyo's Nagari Owned Enterprises (BUMNag) based on financial ratio analysis? Based on the formulation of the problem, the research objective is to determine the financial performance of BumNag Panampuang Saiyo so that the BumNag management and other interested parties get an overview of the financial performance of BumNag Panampuang Saiyo.

\section{METHODS}

\subsection{Financial performance}

[7] performance is the result of work that has a strong relationship with the long-term goals of the organization, and satisfaction for consumers, as well as making a major contribution to economic activity. Furthermore, according [8] Financial Performance is an analysis conducted to see the extent to which a company has implemented proper and correct financial implementation rules. [9] the objectives of performance appraisal include: a). Knowing the skills and abilities of employees b). As a basis for optimal development and utilization of employees, so that their career levels or plans can be directed, promotions and promotions. c). As a basis for planning in the field of personnel, especially improving performance conditions, improving quality and work results. d). Encouraging the creation of a healthy reciprocal relationship between superiors and subordinates. e). Knowing the overall condition of the organization from the staffing sector, especially employee performance. Personally, employees know the strengths and weaknesses of the company so that they can spur its development. g). The results of the job implementation assessment can be useful for research and development in the field of employment. 
[10] states that the benefits of performance appraisal include:

a. Improving work performance with an assessment, both leaders and employees get feedback and they can improve their work or performance.

b. Promote fair occupational health. Accurate assessors can ensure that employees have the opportunity to occupy suitable job positions.

c. Training and development needs Through performance appraisal, employees with low abilities were detected, thus enabling a training program to improve employability

d. Compensation adjustment Through appraisal, leaders can make decisions in determining improvements to compensation and so on.

e. Diagnosing job design errors Poor performance may be a sign of errors in job design. Performance appraisals can help diagnose these errors.

f. Assess the recruitment and selection process. Low performance of new employees may reflect irregularities in the recruitment and selection process.

\subsection{Liquidity Ratio}

[11] The liquidity ratio is a ratio used to measure how liquid a company is. The trick is to compare the components on the balance sheet, namely total current assets with total current liabilities (short-term debt). The types of liquidity ratios are as follows:

\section{a. Current ratio}

[11] is a ratio to measure a company's ability to pay short-term obligations or debt that is due immediately when collected as a whole. In other words, how much current assets (cash, accounts receivable, equipment, inventories and others) are available to cover short-term liabilities or debts that are due soon (maximum 1 year). The formula for finding the current ratio can be used as follows:

\section{Current Ratio $=($ Current Assets $) /($ Short-term}

Liabilities)

Based on formula 1, the higher the current ratio value, the better the ability to pay short-term liabilities using current assets. Meanwhile, if the lower the current ratio value, the lower the ability of current assets to cover short-term debt.

\section{b. Quick Ratio}

[11] quick ratio is a ratio that shows a company's ability to meet or pay its liabilities or current debt (short-term debt) with current assets without taking inventory value into account. This means that this ratio ignores the value of the inventory, by subtracting it from total current assets. This is done because inventories are considered to take relatively longer time to cash in, if the company needs funds quickly to pay its liabilities compared to other current assets. The formula for finding a quick ratio can be used as follows:

Quick Ratio = (Current Assets-Inventory) / (Short-

Term Liabilities)

Based on formula 2, the higher the value of the quick ratio, the better the ability to pay short-term liabilities using current assets after deducting inventory. Meanwhile, if this fast ratio is getting smaller, the lower the ability of current assets after deducting inventory to cover short-term debt.

\section{c. Cash Ratio}

[11] the cash ratio is a tool used to measure how much cash is available to pay debts. Availability of cash can be shown from the availability of cash or cash equivalents such as a checking account or savings account at a bank (which can be withdrawn at any time). It can be said that this ratio shows the true ability of the company to pay its short-term debts. The formula for finding the cash ratio or cash ratio can be used as follows:

Cash Ratio $=($ Cash + Cash Equivalent $) /($ Short-term Liabilities)

Based on Equation (3), the higher the value of the cash ratio, the better the ability to pay short-term obligations using cash + cash equivalents

\subsection{Solvency Ratio}

[11], the solvency ratio is a ratio used to measure the extent to which company assets are financed with debt. The types of solvency ratios are as follows:

\section{a. Debt to Asset Ratio (DAR)}

DAR is a solvency ratio to measure the ratio between total debt and total assets. So, DAR sees how much BUMNag assets are financed by debt or how much BUMNag debt affects asset management [12]. [11], the formula for finding DAR can be used as follows:

\section{Debt to Asset Ratio = $($ Total Liabilities $) /($ Total} Assets)

Based on Equation (4), if the measurement results are high, it means that there is more funding with debt, then it will be more difficult to obtain additional loans because it is feared that they will not be able to cover their debts with the assets they have. Likewise, if the ratio is low, the smaller the company will be financed with debt. 


\section{b. Debt to Equity Ratio (DER)}

DER is the solvency ratio to assess the ratio between debt and equity. This ratio is found by comparing all debt to total equity. This ratio is very useful in determining the amount of funds provided by the borrower (creditors) and the owner of the company [12]. The formula for finding DER is as follows:

Debt to Equity Ratio $=($ Total Liabilities $) /($ Total

Equity)

Based on formula 5, the greater the total liabilities compared to the total equity, the higher the external funding source compared to the internal funding sources. The use of large debt will result in a high interest expense, so that it has an impact on reducing profits.

\section{c. Long Term Debt to Equity Ratio (LTDER)}

LTDER is a solvency ratio to see the comparison of long-term debt with own capital. The purpose of this ratio is to measure how much part of each rupiah of own capital is used as collateral for long-term debt, the smaller the value, the better. According [12], the formula for finding the Long Term Debt to Equity Ratio is as follows:

Long Term Debt to Equity Ratio = $($ Long-term Liabilities) / (Total Equity)

Based on Equation (6), the greater the amount of long-term liabilities compared to the total equity, the higher the funding that comes from outside with a long-term nature compared to internal sources of funding.

\subsection{Activity Ratio}

[11] the activity ratio is a ratio used to measure the effectiveness of a company in using its assets. Or it can also be said that this ratio is used to measure the level of efficiency (effectiveness) of the utilization of company resources. The types of activity ratios are as follows:

\section{a. Total Asset Turnover or Total Assets Turn Over (TATO)}

[11] TATO is a ratio used to measure the turnover of all assets owned by the company and measure how many sales are obtained from each rupiah of assets with the following formula:

Total Asset Turnover $=$ Sales $/($ Total Asset $)$.

Based on formula 7 , the greater the number of long-term liabilities compared to total equity, the higher the long-term external sources of funding compared to internal funding sources. The use of large long-term debt will generate interest expenses, which will affect the profits to be obtained.

\section{b. Fixed Assets Turn Over (FATO)}

[11] FATO is a activity ratio to measure the number of times the funds invested in fixed assets rotate in one period or FATO is used to measure whether BUMNag have fully used their fixed asset capacity or not. To find this ratio, the method is to compare net sales to total fixed assets in a period using the formula:

Fixed Asset Turnover $=$ Sales $/($ Fixed Assets $) ..$

Based on Equation (8), fixed asset turnover measures the overall fixed asset activity to generate sales. The greater the turnover value of fixed assets, the more effective the use of fixed assets is in generating sales.

\section{c. Working Capital Turnover}

[11] Working Capital turnover is a ratio to measure or assess the effectiveness of working capital during a certain period. Working capital in this case uses gross working capital, namely all current assets. The formula for finding working capital turnover is as follows:

$$
\begin{gathered}
\text { Working Capital Turnover }=\text { Sales } /(\text { Working } \\
\text { Capital) } \ldots \ldots \ldots \ldots \ldots \ldots \ldots \ldots \ldots \ldots \ldots \ldots \ldots \ldots \ldots \ldots \ldots \ldots \ldots \ldots \ldots \ldots \ldots
\end{gathered}
$$

Based on Equation (9), the greater the working capital turnover value, the more effective the use of assets in working capital is in generating sales.

\subsection{Profitability Ratio}

[11], the profitability ratio is a ratio to assess the ability to seek profit. This ratio also provides a measure of the level of management effectiveness in generating profit resulting from sales and investment income. The types of profitability ratios are as follows:

\section{a. Net Profit Margin (NPM)}

[11] NPM is a ratio of profitability by comparing earnings after interest and taxes with sales. This ratio shows the company's net income over sales with the following formula:

$$
\text { Net Profit Margin }=(\text { Net Profit }) / \text { Sales }
$$

Based on Equation (10), the higher the results obtained, the better, because it shows the ability to generate net income from sales earned.

\section{b. Return on Assets (ROA)}

[11] Return on assets is the return on assets, which is a ratio that shows the return on the amount 
of assets used. The smaller this ratio the better, and vice versa. This means that this ratio is used to measure the effectiveness of generating profits using assets, using the following formula:

Returns on Asset = (Net Income) $/$ (Total Assets).(11)

Based on Equation (11), the higher the results obtained, the better, because it shows the ability to generate net income using available assets.

\section{c. Return on Equity (ROE)}

[11] Return On Equity is a ratio to measure net profit after tax with own capital. This ratio shows the efficient use of own capital. The higher this ratio, the better and vice versa. The formula for finding return on equity (ROE) is as follows:

Return on Equity = (Net Income) $/$ (Total Equity) $(12)$

Based on Equation (12), the higher the results obtained, the better, because it shows the ability to generate net income using available equity.

\subsection{Research Methods}

This type of research is a quantitative descriptive study. For descriptive analysis with the method of financial ratio analysis, which according [13], explains that descriptive research is research conducted to determine the value of the independent variable, either one or more (independent) variables without making comparisons or linking with other variables.

This research data collection technique uses data collection techniques by means of documentation, interviews and systematic observation, namely in the form of documentation, namely by taking or requesting financial data that has been made related to research problems in the form of financial reports from BUMNag Panampuang Saiyo in Nagari Panampuang, Ampek Angkek District, Agam Regency, West Sumatra Province in the form of Profit and Loss Statement and Balance Sheet for the period 2019. In analyzing the data obtained, the method used is descriptive analysis. Researchers use the analysis method of calculating financial ratios which include liquidity ratios, solvency ratios, activity ratios and profitability ratios.

\section{RESULTS AND DISCUSSION}

\subsection{Results}

The results of the calculation of financial ratios are as follows:
Table 1. Financial Ratio of BumNag Panampuang Saiyo

\begin{tabular}{|r|l|c|}
\hline \multicolumn{1}{|c|}{ No } & \multicolumn{1}{|c|}{ Ratio Type } & $\begin{array}{c}\text { Hasil Perhitungan/ } \\
\text { The calculation } \\
\text { results }\end{array}$ \\
\hline A & Liquidity Ratio & \\
\hline 1 & Current Ratio & $5.059,56$ \\
\hline 2 & Quick Ratio & $2.026,69$ \\
\hline 3 & Cash Ratio & 64,63 \\
\hline & & \\
\hline B & Solvency Ratio & \\
\hline 1 & Debt to Asset Ratio & 0,000077191 \\
\hline 2 & Debt to Equity Ratio & 0,000077197 \\
\hline 3 & Long Term Debt to & \\
\hline C & Activity Ratio & 0 \\
\hline 1 & Total Asset Turn Over & 0,17 \\
\hline 2 & Fix Asset Turn Over & 0,58 \\
\hline 3 & Working Capital Turn & \\
\hline D & Over & 0,42 \\
\hline 1 & Profitability Ratio & \\
\hline 2 & Ret Profit Margin & $-0,16$ \\
\hline 3 & Return On Equity & $-0,0257619$ \\
\hline & & \\
\hline
\end{tabular}

Based on Table 1, it is known that the value of the liquidity ratio consists of current ratio, fast ratio and cash ratio. The current ratio of BumNag Panampuang Saiyo in 2019 has a value of 5,059.56, meaning that IDR 1 short-term liability can be covered by IDR $5,059.56$ current assets. Furthermore, it is also known that the quick ratio for 2019 is 2,026.69, which means that IDR 1 short-term liability is covered by IDR 2,026.69 current assets after deducting the inventory, and for the cash ratio it has a value of 64.63, meaning that IDR 1 obligation currently able to be covered with Rp. 64.63 which came from cash + cash equivalent.

Furthermore, based on Table 1, it is also known about the solvency ratio which includes the debt to assets ratio (DAR), the debt-to-equity ratio (DER) and the long-term debt to equity ratio (LTDER). For DAR, it is known that it has a result of 0.000077191 , meaning that in Rp. 1 of the total assets, Rp. 0.000077191 is funded from liabilities. Then for the DER ratio, it has a value of 0.000077197 , meaning that in the capital structure, if there is IDR 1 equity composition, debt will have a composition of IDR 0.000077197. Meanwhile, the LTDER ratio has a value of 0 because in financial reporting, BumNag has no long-term debt so that the LTDER value is 0 . 
Then based on Table 1, it is also known that the activity ratio consisting of the total asset turnover ratio (TATO), the fixed asset turnover ratio (FATO) and the working capital turnover ratio (Working Capital Turn Over). The TATO value is 0.17 times, indicating that the sales value is smaller than the total assets, and by using Rp. 1 the total assets are able to generate Rp. 0.17 sales. Meanwhile, the FATO value is 0.58 times, indicating that the sales value is smaller than the total fixed assets, and using Rp 1, the total fixed assets are able to generate Rp 0.58 sales. Furthermore, the value of Working Capital Turn Over is 0.42 times, indicating that the sales value is smaller than the gross working capital value, and by using IDR 1 the total gross working capital is able to generate IDR 0.42 sales.

The profitability ratio of BumNag Panampuang Saiyo shows a negative value for both the net profit margin ratio, ROA and ROE. The net profit margin shows a value of -0.16 , the value of Return On Assets (ROA) is -0.0257599, and the Return On Equity has a value of -0.0257619 . Based on these results, it shows that sales, utilization of assets and utilization of equity have not been able to generate profits for BumNag Panampuang Saiyo

\subsection{Discussion}

The liquidity ratio of BumNag Panampuang Saiyo has a high value, namely a current ratio with a value of 5,059.56 then a quick ratio with a value of $2,026.69$ and a cash ratio with a value of 64.63 so that it is able to cover all its short-term liabilities using both current assets, current assets after deducting inventory or by using cash + cash equivalents. However, having a lot of assets has an impact on the activity ratio. In the activity ratio, a small value of 1 is obtained for both the total asset turnover ratio, the fixed asset turnover ratio and the working capital turnover ratio because it has high total assets and fixed assets. The high amount of assets is able to cover short-term liabilities but is not able to increase sales volume. The BumNag management must take a policy to take advantage of assets owned, both current and non-current assets, so that sales volume increases while still paying attention to the ratio of debt to assets and capital. The increasing sales volume will also have an impact on the profitability ratio, so it is expected that the net margin ratio, $\mathrm{ROA}$ and $\mathrm{ROE}$ can have a positive value.

The Financial Solvency Ratio of BumNag Panampuang Saiyo has a small value of 1, both for Debt to Asset Ratio (DAR) with a value of 0.000077191, Debt to Equity Ratioa (DER) with a value of 0.000077197 and Long-Term Debt to Equity
Ratio (LTDER) with value 0. By having a solvency ratio value smaller than 1 , it can be concluded that BumNag Panampuang Saiyo prioritizes the use of internal capital in the form of equity to carry out its business activities. This is of course very good, so that the dependence of funding on external parties can be minimized especially with the large number of assets, the BumNag management can carry out business development without having to be burdened with debts to creditors.

The financial activity ratio of BUMNag Panampuag Saiyo in 2019 has a small value of 1, both for the total asset turnover ratio (TATO) of 0.17 times the value, the fixed asset turnover ratio (FATO) with a value of $0.58 \mathrm{x}$ and the working capital turnover ratio with value of 0.42 times, this shows that during 2019 the use of assets in the form of total assets, fixed assets and working capital (current assets) has not been able to achieve sales above the value of the assets used, meaning that the management of BumNag Panampuang Saiyo must make more efforts so that for the following year period in order to be able to more productively use all resources, including total assets, fixed assets and current assets.

The financial profitability ratio of BumNag Panampuang Saiyo in 2019 has a negative value, both for the ratio of net margin, ROA and ROE. This illustrates that the sales received during 2019 have not been able to generate profits for BumNag. Furthermore, the utilization of the total assets of BumNag Panampuang Saiyo and the use of funding from its own capital for 2019 have not been able to generate a net profit for BumNag Panampuang Saiyo. For the next period, the management of BumNag Panampuang Saiyo must strive to maximize the use of assets that come mostly from their own equity to generate higher sales, so as to generate profits for BumNag Panampuang Saiyo.

\section{CONCLUSION}

The conclusion of this research shows that the financial performance of BumNag Panampuang Saiyo in terms of liquidity ratios shows a good performance because BumNag Panampuang Saiyo is able to cover its short-term liabilities by using current assets, current assets after deducting from inventories and by using cash + cash equivalents. Likewise, the solvency ratio of BumNag Panampuang Saiyo shows good performance in a business that is being run by prioritizing the use of internal funds rather than the use of external funds. As for the activity ratio and profitability ratio, it shows that BumNag Panampuang Saiyo's performance has not been optimal for 2019, because the utilization of total assets, fixed assets 
and working capital has not been able to generate sales or income above the total value of assets, fixed assets and working capital, so that because it has not been able to generate sales which are expected to have an impact on the financial condition of BumNag Panampuang Saiyo which is still in a loss condition.

\section{REFERENCES}

[1] Pemerintah Indonesia. Undang-Undang Republik Indonesia Nomor 6 Tahun 2014 Tentang Desa. Lembaran Negara Republik Indonesia Tahun 2014 Nomor 7. Jakarta. 2014

[2] Lokadata. Jumlah Bumdes di Indonesia, 20152019. https://lokadata.id/data/jumlah-bumdesdi-indonesia-2015-2019-1592899207, 23/06/2020. Accessed 10/9/2020.

[3] Pemerintah Indonesia.Peraturan Menteri Dalam Negeri Republik Indonesia Nomor 113 Tahun 2014 Tentang Pengelolaan Keuangan Desa. Berita Negara Republik Indonesia Tahun 2014 Nomor 2093. Jakarta. 2014

[4] Pemerintah Indonesia. Peraturan Menteri Desa, Pembangunan Daerah Tertinggal, dan Transmigrasi Republik Indonesia Nomor 4 Tahun 2015 Tentang Pendirian, Pengurusan dan Pengelolaan, dan Pembubaran Badan Usaha Milik Desa. Berita Negara Republik Indonesia Tahun 2015 Nomor 296. Jakarta. 2015

[5] Badan Usaha Milik Nagari Panampuang Saiyo. Anggaran Dasar Badan Usaha Milik Nagari Panampuang Saiyo. 2017

[6] Redaksi Prokabar. BUMNag Panampuang Saiyo Promosikan Pinjaik Patah di Pesta Pulau Penang. 7 Desember 2019. Accessed tanggal 10/9/2020.

[7] Wibowo. Manajemen Kinerja. Jakarta: Rajawali Pers. 2013.

[8] Fahmi, Irham. Analisis Laporan Keuangan. Alfabeta. Bandung. 2012.

[9] Simamora, Henry. Pengertian Kinerja Keuangan. Jakarta: Salemba Empat. 2004.

[10] Munawir, S. Analisis Laporan Keuangan. Yogyakarta: Liberty. 2014.

[11] Kasmir. Analisis Laporan Keuangan. Jakarta: Rajawali Pers, 2016.
[12] Horne, James C. Van dan John M Wachowicz Jr. Prinsip-Prinsip Manajemen Keuangan (Edisi 13). Jakarta : Salemba Empat. 2012.

[13] Sugiyono. Manajemen Penelitian Kualitatif, Kuantitatif dan Kombinasi. Bandung: Penerbit Alfabeta. 2012.

[14] Irawati and Martanti. Transparansi Pengelolaan Laporan Keuangan Bumdes Terhadap Pelaporan Aset Desa (Studi Fenomenologi Pada BUMDes Desa Karangbendo Kec Ponggok Kab Blitar). Prosiding Seminar Nasional dan Call For Paper Ekonomi dan Bisnis (SNAPER-EBIS 2017) - Jember, 27-28 Oktober 2017 (hal 4151) ISBN : 978-602-5617-01-0. 2017.

[15] Sugiyanto. Pendampingan Penyusunan Laporan Keuangan BUMDes Tirto Wening Makmur Desa Gondosuli, Kecamatan Bulu, Kabupaten Temanggung. Intervensi Komunitas Jurnal Pengabdian Masyarakat E-ISSN: 2714-691X OJS: http://ojs.itb-ad.ac.id/index.php/IK. 2020

[16] Ramadhani, Ramadhani. Analisis Perbandingan Kinerja Keuangan Badan USAha Milik Desa (Bumdes) Di Kabupaten Rokan Hulu. Jurnal Mahasiswa Prodi Akuntansi UPP, vol. 2, no. 1, 2016.

[17] Kasnadi,NP. Sulaman Terawang Pinjaik Patah Panampuang Saiyo Ikuti Pameran Kemendes. https://www.topsatu.com/sulaman-terawangpinjaik-patah-panampuang-saiyo-ikuti-pameran = kemendes/ 14 September 2019. Accessed tanggal 11/10/2020

[18] Maharyani, Govindha Zahra, et.al. Analisis Rasio Keuangan Sebagai Tolok Ukur Kinerja Keuangan Badan Usaha Milik Desa (Bumdes) Arum Dalu Ngabar. Asset: Jurnal Ilmiah Bidang Manajemen dan Bisnis Vol. 1, No. 2 (2018): December, pp. 35-46 Economic Faculty, Universitas Muhammadiyah Ponorogo 35 pISSN 2614-5502 / e-ISSN 2614-72462. 2018.

[19] Sari, Purnama and Sri Wahyuni Ummur. Analisis Kinerja Badan Usaha Milik Desa (Bumdes) Didesa Pohuwato Kabupaten Pohuwato. Accountia Journal (Accounting Trusted, Inspiring, Authentic Journal) Vol.3, No.2, October 2019, pp. 426- 4 ISSN 26205335 (Online), ISSN 2622-8270 (Print). 2019.

[20] Qosjim, Ach. Analisis Kinerja BUMDes di Kabupaten Lumajang (Performance Analysis BUMDes in Jember District). Journal Ekuilibrium, 2017, Volume II (1) : 10-17. 2017 